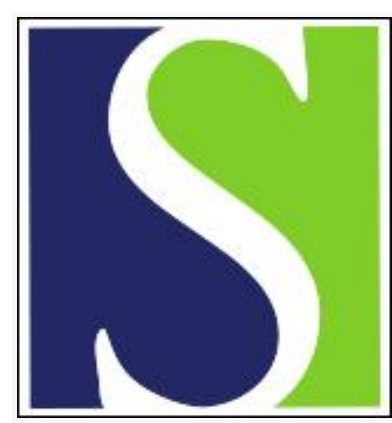

Scand J Work Environ Health 1993;19(3):200-207

https://doi.org/10.5271/sjweh.1322

Issue date: 01 Jun 1993

Effect of the reduction of skin contamination on the internal dose of creosote workers exposed to polycyclic aromatic hydrocarbons

by Van Rooij JGM, Van Lieshout MA, Bodelier-Bade MM, Jongeneelen FJ

Affiliation: Department of Toxicology, Faculty of Medical Sciences, University of Nijmegen, PO Box 9101, 6500 HB Nijmegen, The Netherlands.

Key terms: biological monitoring; coveralls; creosote worker; dermal exposure; exposure; intervention study; occupational exposure; polycyclic aromatic hydrocarbon; skin contamination; skin monitoring; Tyvek ${ }^{\circledR}$

This article in PubMed: www.ncbi.nlm.nih.gov/pubmed/8367698 


\title{
Effect of the reduction of skin contamination on the internal dose of creosote workers exposed to polycyclic aromatic hydrocarbons
}

\author{
by Joost GM Van Rooij, MSc, Eugenie MA Van Lieshout, MSc, Monika M Bodelier-Bade, BSc, \\ Frans J Jongeneelen, PhD'
}

\begin{abstract}
VAN ROOIJ JGM, VAN LIESHOUT EMA, BODELIER-BADE MM, JONGENEELEN FJ. Effect of the reduction of skin contamination on the internal dose of creosote workers exposed to polycyclic aromatic hydrocarbons. Scand J Work Environ Health 1993;19:200-7. Ten creosote-exposed workers of a wood impregnation plant participated in this study, which took place in two consecutive weeks

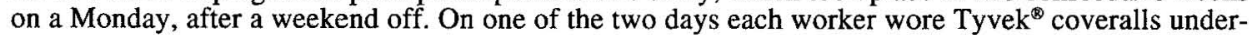
neath his normal workclothes. Dermal contamination measurements (pyrene on exposure pads) and biological monitoring (urinary 1-OH-pyrene) were performed to measure the reduction of both the skin contamination and the internal dose. The total pyrene skin contamination of workers not wearing coveralls ranged between 47 and $1510 \mu \mathrm{g} \cdot \mathrm{d}^{-1}\left(0.2-7.5 \mu \mathrm{mol} \cdot \mathrm{d}^{-1}\right)$. On the average, the coveralls reduced the pyrene contamination on the workers' skin by about 35 (SD 63)\%. The excreted amount of 1-OH-pyrene in urine decreased significantly from 6.6 to $3.2 \mu \mathrm{g}$ (30.2 to $14.7 \mathrm{nmol})$. Multiple regression analysis showed that skin contamination by polycylic aromatic hydrocarbons is the main determinant of the internal exposure dose of creosote workers.
\end{abstract}

Key terms: biological monitoring, coveralls, dermal exposure, occupational exposure, intervention study, skin monitoring, Tyvek ${ }^{\circledR}$.

Creosote oil, a blend of coal-tar distillation fractions, is used as a wood preservative, mainly to impregnate railroad crossties. Creosotes are mixtures of hundreds of different compounds, of which 90 have been identified (1). Polycyclic aromatic hydrocarbons (PAH), mostly unsubstituted, generally account for at least $75 \%$ of creosote (2).

Direct contact with creosote (both liquid and vapor) can cause skin irritation. In combination with exposure to sunlight, it can result in phototoxic contact eczema.

Mutagenic activities have been shown for the fractions having the highest boiling point ranges $\left(>290^{\circ} \mathrm{C}\right)(3)$. In addition topical application of creosote to experimental animals has induced deoxyribonucleic acid (DNA) damage in tissues such as skin and lungs (4). The International Agency for Research on Cancer has stated that there is sufficient evidence for the carcinogenicity of creosote in experimental animals and that there is limited evidence that creosotes derived from coal tar are carcinogenic in humans (5). A recent study among 922 creosote-exposed wood impregnators in Sweden and Norway

Department of Toxicology, Faculty of Medical Sciences, University of Nijmegen, Nijmegen, The Netherlands.

Reprint requests to: Mr JGM Van Rooij, Department of Toxicology, Faculty of Medical Sciences, University of Nijmegen, PO Box 9101, 6500 HB Nijmegen, The Netherlands. showed an increased risk for lip cancer and nonmelanoma skin cancer (6).

The body burden of PAH in workers is mainly determined by respiratory intake and dermal absorption, but the extent of exposure received from both routes is unknown. In a previous study in the primary aluminum industry, we found that dermal PAH contamination showed a higher correlation with internal dose than the breathing-zone air concentration (7). For coke-oven workers exposed to PAH, a quantitative assessment of both dermal and respiratory uptake revealed that a mean percentage of $75 \%$ of total pyrene uptake enters the body through the skin (8). In these studies substantial PAH contamination was found on the skin, even when covered by workclothes.

In order to determine the significance of dermal exposure among creosote workers, an intervention study was designed in which dermal exposure was reduced to a minimum level by highly protective clothing. Protective-barrier clothing is used extensively in industries in which workers are exposed to potentially hazardous chemicals, and considerable effort is made to define the barrier properties of various materials towards chemicals like antineoplastic drugs, polychlorinated biphenyls, and organic solvents $(9-11)$. These studies show that the time and rate of permeation are dependent on both the test chemical and the clothing material. Clothing made from Tyvek ${ }^{\otimes}, 2$ a spun-bonded olefin sheet structure

\footnotetext{
2 Tyvek is a registered trademark of DuPont.
} 
of $100 \%$ polyethylene, was selected to reduce dermal PAH contamination in this investigation. The permeability of Tyvek $^{(B)}$ for particles is very low ( $<0.1 \%$ for particles with a diameter $>0.5 \mu \mathrm{m}$; source: Du Pont product information), and the material is more comfortable to wear than clothing made from laminated and coated material (9).

In the present study we investigated the effect of reducing $\mathrm{PAH}$ contamination on skin on the internal dose of creosote-exposed workers of a wood impregnation plant.

\section{Subjects and methods}

This study was conducted in a wood preserving plant in The Netherlands in October 1991. In this plant railroad crossties (also known as sleepers) are impregnated with creosote oil and provided with metal plates for fitting the rails. About 8000001 of creosote oil is used annually to impregnate about 200000 wooden sleepers (one sleeper is about $0.1 \mathrm{~m}^{3}$ and weighs 90 to $100 \mathrm{~kg}$ ).

Two or three times a day a charge of 400 wooden sleepers is impregnated in a cylinder under a pressure of $12.2 \cdot 10^{5} \mathrm{~Pa}$, during $2.5 \mathrm{~h}$. After the sleepers have been impregnated, the oil is pumped out of the cylinder, and the air in the cylinder is sucked almost to a vacuum to remove superfluous creosote oil. Three men are occupied around the cylinders in operations such as controlling the process, transporting the wooden sleepers on trucks into and out of the cylinders, and opening and closing the covers of the cylinder. After the impregnation process, the trucks are driven from the cylinder to the open air, where the newly impregnated wood is left to let the excess creosote evaporate overnight. Next the sleepers are provided with metal plates in an assembly hall. The assembly is done manually by 10 men. The workers of the plant can be exposed to PAH-containing creosote volatiles, either emitted from vacuum-pump exhaust, from the exhaust of the creosote dehydra- tion installation, or from the newly impregnated wood during evaporation. Skin contamination is possible through deposition from the air or through direct skin contact with contaminated surfaces or workclothes.

\section{Study design}

Three workers who worked near the impregnation cylinders and seven workers from the assembly hall volunteered for this study. Personal data are given in table 1. Exposure measurements were performed in two consecutive weeks on a Monday, after a weekend off. On one Monday the workers wore Tyvek ${ }^{\circledR}$ coveralls, gloves, and socks (of the same material) (figure 1) underneath their normal workclothes. On the other Monday they did not wear extra protective clothing underneath their workclothes. On the two Mondays we measured the PAH contamination on skin and the PAH concentration in the breathing zone of the 10 workers. In the same two weeks, urine samples were collected from Sunday morning (from 0800 on) up to and including Tuesday morning (to 0600) for the assessment of the internal exposure to $\mathrm{PAH}$. All of the workers had a normal workweek followed by a weekend off before each day of measurement.

Pyrene was used as the marker compound for PAH contamination on the skin and in breathing-zone air. 1-OH-pyrene was used as the biological indicator for internal PAH exposure. This metabolite of pyrene is increasingly being used and is more and more accepted as a biological indicator of the internal dose of PAH (12-16). Interviews were conducted by a trained interviewer using a questionnaire about personal characteristics, including age, weight, height, smoking habits, and alcohol consumption.

\section{Skin contamination measurements}

For the assessment of the PAH contamination on the natural skin, we pasted six exposure pads on different spots on the skin of the workers (ie, on the jaw,

Table 1. Personal data and characteristics of the creosote workers.

\begin{tabular}{|c|c|c|c|c|c|c|c|}
\hline $\begin{array}{l}\text { Personal } \\
\text { code }\end{array}$ & $\begin{array}{l}\text { Function/ } \\
\text { work location }\end{array}$ & $\begin{array}{c}\text { Age } \\
\text { (years) }\end{array}$ & $\begin{array}{c}\text { Alcohol } \\
\text { use }^{a}\end{array}$ & Smokingb & $\begin{array}{l}\text { Height } \\
\text { (cm) }\end{array}$ & $\begin{array}{l}\text { Body } \\
\text { weight } \\
\text { (kg) }\end{array}$ & $\begin{array}{l}\text { Estimated } \\
\text { surface area } \\
\text { of skin } \\
\left(\mathrm{m}^{2}\right)\end{array}$ \\
\hline $\begin{array}{r}1 \\
2 \\
3 \\
4 \\
5 \\
6 \\
7 \\
8 \\
9 \\
10\end{array}$ & $\begin{array}{l}\text { Assembly hall } \\
\text { Assembly hall } \\
\text { Assembly hall } \\
\text { Assembly hall } \\
\text { Assembly hall } \\
\text { Assembly hall } \\
\text { Assembly hall } \\
\text { Cylinder } \\
\text { Cylinder } \\
\text { Cylinder }\end{array}$ & $\begin{array}{l}21 \\
19 \\
59 \\
54 \\
24 \\
33 \\
45 \\
30 \\
39 \\
41\end{array}$ & $\begin{array}{l}0 \\
1 \\
1 \\
0 \\
1 \\
1 \\
1 \\
1 \\
1 \\
1\end{array}$ & $\begin{array}{l}1 \\
1 \\
0 \\
0 \\
1 \\
1 \\
1 \\
0 \\
0 \\
0\end{array}$ & $\begin{array}{l}177 \\
180 \\
175 \\
172 \\
181 \\
183 \\
183 \\
176 \\
172 \\
172\end{array}$ & $\begin{array}{l}71 \\
67 \\
80 \\
78 \\
78 \\
82 \\
73 \\
91 \\
85 \\
85\end{array}$ & $\begin{array}{l}1.87 \\
1.85 \\
1.96 \\
1.91 \\
1.98 \\
2.04 \\
1.94 \\
2.07 \\
1.98 \\
1.98\end{array}$ \\
\hline
\end{tabular}

a Alcohol use: $1=$ yes, $0=$ no.

b Smoking of tobacco: $1=$ yes, $0=$ no.

c Surface area of the skin was calculated with the following formula: surface area of skin $=71.84 \cdot$ body weight ${ }^{0.425} \cdot{ }^{\text {height }}{ }^{0.725}$ (17). 
(a)

(b)

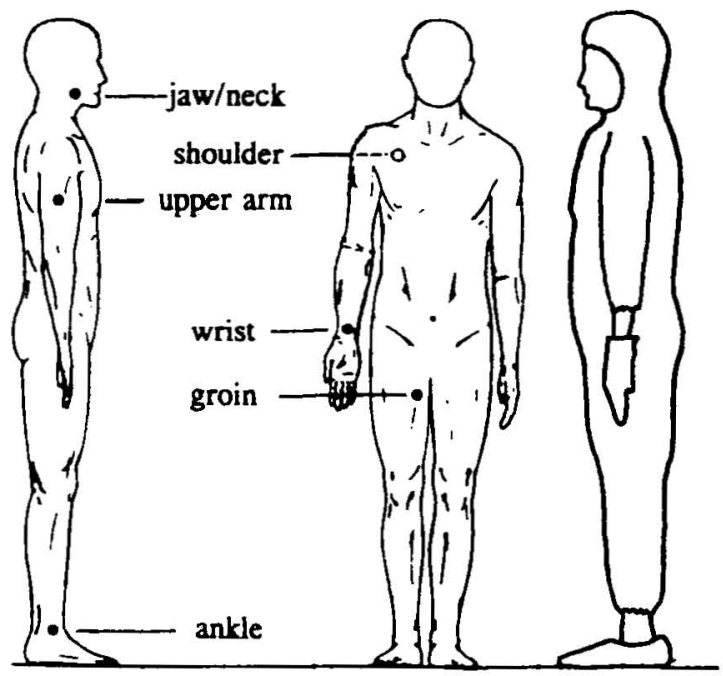

(c)

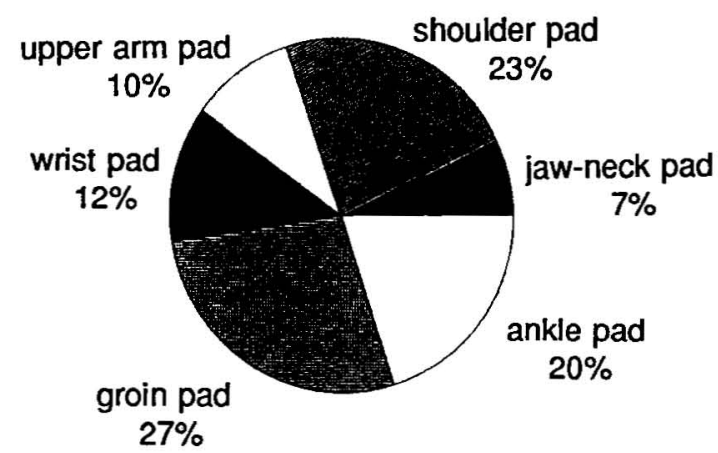

Figure 1. Skin sites where exposure pads were pasted for the monitoring of dermal polycyclic aromatic hydrocarbon contamination (a), the coveralls as applied in this study to reduce the skin contamination (b), and the percentage of the total body area that each pad was assumed to represent (c).

the shoulder, the upper arm, the wrist, the groin, and the ankle) during workhours (figure 1). The exposure pads were round monitoring devices (diameter $60 \mathrm{~mm}$ ) with a small monitoring area (diameter 18 $\mathrm{mm}$ ). Flexible polypropylene filter material (Gelmann Sciences, Ann Arbor, Michigan, United States) was used as the adsorbing material in the exposure pad. The design of the exposure pad has been explained elsewhere (17).

Immediately after the exposure, the pads were removed, packed in aluminum foil, and stored at $-20^{\circ} \mathrm{C}$ until the analysis. A circular piece of the polypropylene adsorbing material with a diameter of $15 \mathrm{~mm}$ $\left(1.77 \mathrm{~cm}^{2}\right)$ was punched out for the analysis. The exposure pads were ultrasonically extracted with $10 \mathrm{ml}$ of dichloromethane for $10 \mathrm{~min}$. Under a gentle flow of nitrogen (at $40^{\circ} \mathrm{C}$ ) the solvent was evaporated to dryness, and the residue was dissolved in $2 \mathrm{ml}$ of methanol. After centrifugation of the sample, the supernatant was analyzed for pyrene with reversed- phase high-performance liquid chromatography (HPLC). Aliquots $(20 \mu 1)$ of the samples were injected fully automatically from the vials onto a Vydac TP RP 18 column $(150 \times 4.6 \mathrm{~mm} ; 10 \mu \mathrm{m}$ particles; column temperature $40^{\circ} \mathrm{C}$; supplier Separations Group, Hespesia, California, United States). The composition of the solvent was programmed at a linear gradient from a water:methanol ratio of $42: 58$ to $6: 94$ for $50 \mathrm{~min}$, the solvent flow was $1.0 \mathrm{ml}$. $\mathrm{min}^{-1}$. The apparatus was equipped with a fluorescence spectrophotometer (Jasco 820-FP Spectroscopic Co, Japan). The recovery of pyrene from exposure pads spiked with creosote oil was $92 \%$.

Using the pyrene contamination on the six exposure pads, an assessment was made of the total daily pyrene contamination on the skin of the workers, as proposed in a previous study (8). In this assessment it was assumed that each of the six pads represented a skin region with a certain surface area. (See figure 1.) The surface areas of the different skin regions were calculated with the anatomical dimensions of the 50 percentile man, as described by Popendorf \& Leffingwell (18). The total body area of the workers (table 1) was calculated with a formula based on height and weight, as proposed by DuBois \& DuBois (19).

\section{Personal air sampling}

During workhours, personal samples of airborne particulates in the breathing zone of the worker were collected on a polytetrafluoroethylene (PTFE) filter (diameter $25 \mathrm{~mm}$, pore size $0.5 \mu \mathrm{m}$ ). A sorbent sample tube, containing XAD-2 resin as the sorbent (ORBO-43, supplier Supelco Inc, Bellefonte, Pennsylvania, United States), was placed directly behind the particle sampler to trap gaseous PAH. The sampler was equipped with a cone over the face. With a suction flow of $21 \cdot \mathrm{min}^{-1}$, a suction velocity of $1.25 \mathrm{~m} \cdot \mathrm{s}^{-1}$ was reached in the entrance of the sampler, in accordance with recommendations of the Staubforschungs Institute in Germany (20).

After the sampling, the filters and the XAD-2 resin from the sorbent sample tubes were stored in the dark at $-20^{\circ} \mathrm{C}$. The samples were analyzed within three weeks. For the PTFE filters and the XAD-2 resin from the sorbent sample tubes, the same method of sample preparation and analysis was used as for the exposure pads. (See the section Skin Contamination Measurements.) The recovery of pyrene on the PTFE filters and the XAD-2 resin was $88 \%$.

\section{1-OH-pyrene in urine}

All of the urine voided from Sunday morning (from 0800 on) to Tuesday morning (at 0600) was sampled. The volunteers registered the volume and the hour of voidance. The urine samples were stored at $-20^{\circ} \mathrm{C}$ until the analysis. Metabolites of pyrene in urine were deconjugated by enzymatic hydrolysis, and a solid phase sample clean-up was applied. HPLC anal- 
ysis allowed the determination of the sum of free and conjugated 1-OH-pyrene in nanomoles per liter. A full description of the method has been presented elsewhere (21). The reproducibility of the analysis of urinary 1-OH-pyrene in this study was determined by a repeated analysis of 44 randomly selected urine samples. The coefficient of variation of the analysis was $8.0 \%$.

\section{Statistical analysis}

The exposure variables are presented with the median because this measure of central location is more representative of a skewed distribution of data than the arithmetic mean. Data below the detection limit were processed as having the numeric value of half the detection limit. The Shapiro-Wilk test was used to test the normality of the input data. Depending on the normality of the data, either the paired t-test or the Wilcoxon signed rank test was applied to determine the significance of the differences of the means. Correlation was quantified with Spearman's rank correlation analysis $\left(\mathrm{r}_{\mathrm{s}}\right)$. Multiple regression analysis was carried out to study the relationship between the dermal and respiratory exposure and the internal dose. The residuals were checked for the normal distribution assumption. None of the analyses showed major deviation from this assumption.

\section{Results}

\section{Skin contamination}

Figure 2 shows the pyrene contamination on the exposure pads pasted at six skin sites on the day with and without coveralls. The extra protective clothing only reduced the PAH contamination on the pads of the shoulder, upper arm, and groin. At the other skin sites (jaw-neck, ankle, and wrist) no significant reduction was found. The figure also illustrates the dispersal of the pyrene contamination on the skin of the workers. Without extra protective clothing, the high- est pyrene contamination was found on the wrist (median $82 \mathrm{ng} \cdot \mathrm{cm}^{-2}$ or $405 \mathrm{pmol} \cdot \mathrm{cm}^{-2}$ ) followed by the jaw-neck (median $10 \mathrm{ng} \cdot \mathrm{cm}^{-2}$ or $49 \mathrm{pmol} \cdot \mathrm{cm}^{-2}$ ). The shoulder, upper arm, groin, and ankle showed substantial contamination (average of about $4 \mathrm{ng}$. $\mathrm{cm}^{-2}$ or $18 \mathrm{pmol} \cdot \mathrm{cm}^{-2}$ ) despite the fact that these skin sites were covered with workclothes.

The results of the estimation of the total skin contamination on the two days of measurement are presented in table 2 . The total pyrene skin contamination ranged from 47 to about $1500 \mu \mathrm{g} \cdot \mathrm{d}^{-1}(0.2$ to about $7.5 \mu \mathrm{mol} \cdot \mathrm{d}^{-1}$ ) on the day the workers did not wear coveralls. On the average, wearing the coveralls resulted in a reduction of the skin contamination by 35 (SD 63)\%. Three of the 10 workers showed a higher skin contamination despite their wearing of coveralls. Pyrene did not penetrate the Tyvek ${ }^{\circledR}$ material of the coveralls because no contamination was detected on exposure pads pasted on the inside of the coveralls (sleeve and head cover), with the monitoring area towards the material of the coveralls (data not shown).

\section{Breathing-zone concentrations}

The total pyrene concentration in the breathing zone of the workers was calculated as the sum of the gaseous pyrene concentration and the particulate pyrene concentration. The total pyrene concentration ranged from 0.3 to $3.0 \mu \mathrm{g} \cdot \mathrm{m}^{-3}$ (1.5 to $\left.14.8 \mathrm{nmol} \cdot \mathrm{m}^{-3}\right)$. On the average, $47 \%$ of the pyrene was in the gas phase. On the day the workers wore coveralls, the mean pyrene concentration in the air was $1.2 \mu \mathrm{g} \cdot \mathrm{m}^{-3}$ $\left(5.9 \mathrm{nmol} \cdot \mathrm{m}^{-3}\right)$; on the day without the coveralls, it was $0.9 \mu \mathrm{g} \cdot \mathrm{m}^{-3}\left(4.5 \mathrm{nmol} \cdot \mathrm{m}^{-3}\right)($ table 2$)$. The highest pyrene concentrations in the breathing-zone air were measured for workers close to the impregnation cylinders (workers 8 and 10).

\section{Internal dose}

Figure 3 illustrates the effect of wearing coveralls on the urinary 1-OH-pyrene excretion rate of worker 1 .

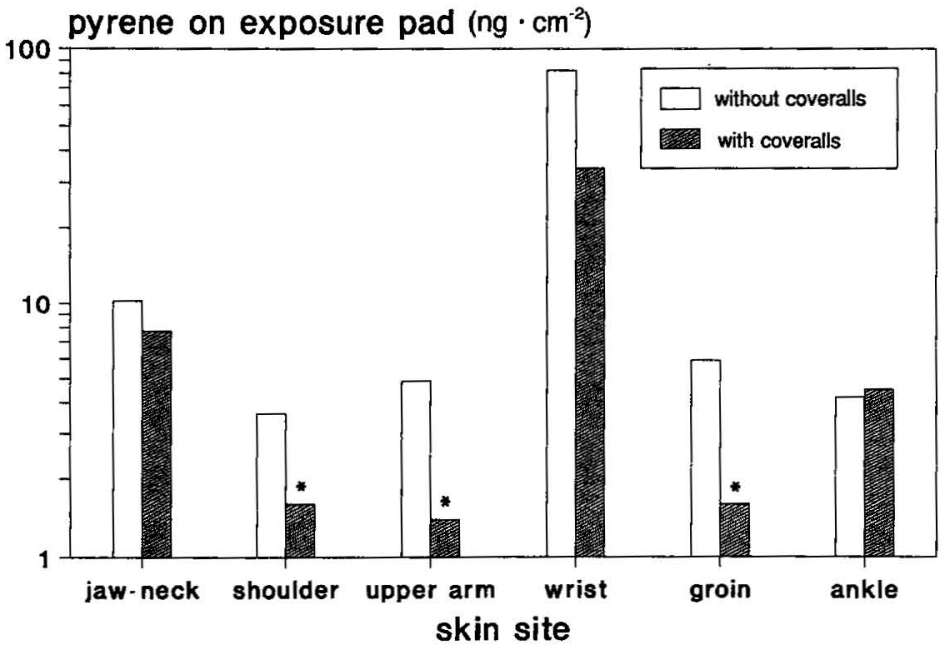

Figure 2. Effect of the coveralls on the pyrene contamination on the exposure pads pasted on six skin sites (median, $\mathrm{N}=10)\left({ }^{*} \mathrm{P} \leq 0.05\right)(1 \mathrm{ng}=4.94 \mathrm{pmol})$ 
Table 2. The effect of the coveralls on the pyrene skin contamination and internal dose (urinary 1-OH-pyrene) of $10 \mathrm{creosote}$ workers. ( $1 \mu \mathrm{g}$ pyrene $\approx 4.94 \mathrm{nmol}, 1 \mu \mathrm{g} 1-\mathrm{OH}$-pyrene $=4.58 \mathrm{nmol}$ )

\begin{tabular}{|c|c|c|c|c|c|c|c|c|c|}
\hline \multirow{2}{*}{ Worker } & \multicolumn{3}{|c|}{$\begin{array}{l}\text { Skin contamination } \\
\text { ( } \mu \mathrm{g} \text { pyrene on skin) }\end{array}$} & \multicolumn{3}{|c|}{$\begin{array}{c}\text { Internal dose } \\
\text { ( } \mu \mathrm{g} 1-\mathrm{OH} \text {-pyrene in urine) }\end{array}$} & \multicolumn{3}{|c|}{$\begin{array}{l}\text { Air concentration } \\
\left(\mu \mathrm{g} \text { pyrene } \cdot \mathrm{m}^{-3}\right)\end{array}$} \\
\hline & $\begin{array}{l}\text { Without } \\
\text { coveralls }\end{array}$ & $\begin{array}{l}\text { With } \\
\text { coveralls }\end{array}$ & Difference $^{b}$ & $\begin{array}{l}\text { Without } \\
\text { coveralls }\end{array}$ & $\begin{array}{l}\text { With } \\
\text { coveralls }\end{array}$ & Difference $^{b}$ & $\begin{array}{l}\text { Without } \\
\text { coveralls }\end{array}$ & $\begin{array}{l}\text { With } \\
\text { coveralls }\end{array}$ & Difference ${ }^{b}$ \\
\hline $\begin{array}{r}1 \\
2 \\
3 \\
4 \\
5 \\
6 \\
7 \\
7 \\
8 \\
9 \\
10\end{array}$ & $\begin{array}{r}387 \\
377 \\
139 \\
47 \\
236 \\
528 \\
1368 \\
1511 \\
316 \\
120\end{array}$ & $\begin{array}{r}90 \\
379 \\
48 \\
77 \\
144 \\
122 \\
137 \\
433 \\
39 \\
216\end{array}$ & $\begin{array}{r}297 \\
-2 \\
91 \\
-30 \\
93 \\
406 \\
1231 \\
1077 \\
277 \\
-96\end{array}$ & $\begin{array}{r}9.8 \\
2.3 \\
2.9 \\
0.7 \\
5.7 \\
12.7 \\
10.1 \\
12.2 \\
7.6 \\
2.6\end{array}$ & $\begin{array}{l}2.0 \\
4.6 \\
1.6 \\
1.3 \\
4.9 \\
5.3 \\
1.5 \\
3.0 \\
2.9 \\
4.7\end{array}$ & $\begin{array}{r}7.7 \\
-2.4 \\
1.3 \\
-0.6 \\
0.7 \\
7.3 \\
8.5 \\
9.2 \\
4.6 \\
-2.1\end{array}$ & $\begin{array}{l}1.1 \\
0.7 \\
0.9 \\
0.3 \\
0.5 \\
1.2 \\
0.9 \\
1.0 \\
0.9 \\
1.3\end{array}$ & $\begin{array}{l}0.7 \\
1.3 \\
0.6 \\
0.8 \\
1.7 \\
0.6 \\
0.4 \\
2.5 \\
0.4 \\
3.0\end{array}$ & $\begin{array}{r}0.4 \\
-0.6 \\
0.3 \\
-0.4 \\
-1.2 \\
0.5 \\
0.5 \\
-1.5 \\
0.5 \\
-1.8\end{array}$ \\
\hline $\begin{array}{l}\text { Mean } \\
\text { Median }\end{array}$ & $\begin{array}{l}503 \\
346\end{array}$ & $\begin{array}{l}158 \\
122\end{array}$ & $\begin{array}{l}334 \\
185^{c}\end{array}$ & $\begin{array}{l}6.6 \\
6.6\end{array}$ & $\begin{array}{l}3.2 \\
2.9\end{array}$ & $\begin{array}{l}3.4^{c} \\
3.0\end{array}$ & $\begin{array}{l}0.87 \\
0.91\end{array}$ & $\begin{array}{l}1.21 \\
0.65\end{array}$ & $\begin{array}{l}-0.33 \\
-0.07\end{array}$ \\
\hline
\end{tabular}

a The amount of 1-OH-pyrene excreted during a period of $22 \mathrm{~h}$ (exposure took place during the first $8 \mathrm{~h}$ of this period).

b Difference between the day without coveralls and the day with coveralls.

c The reduction was statistically significant $(P \leq 0.05)$.

\section{1-OH-pyrene excretion rate $\left(\mathrm{nmol} \cdot \mathrm{h}^{-1}\right)$}

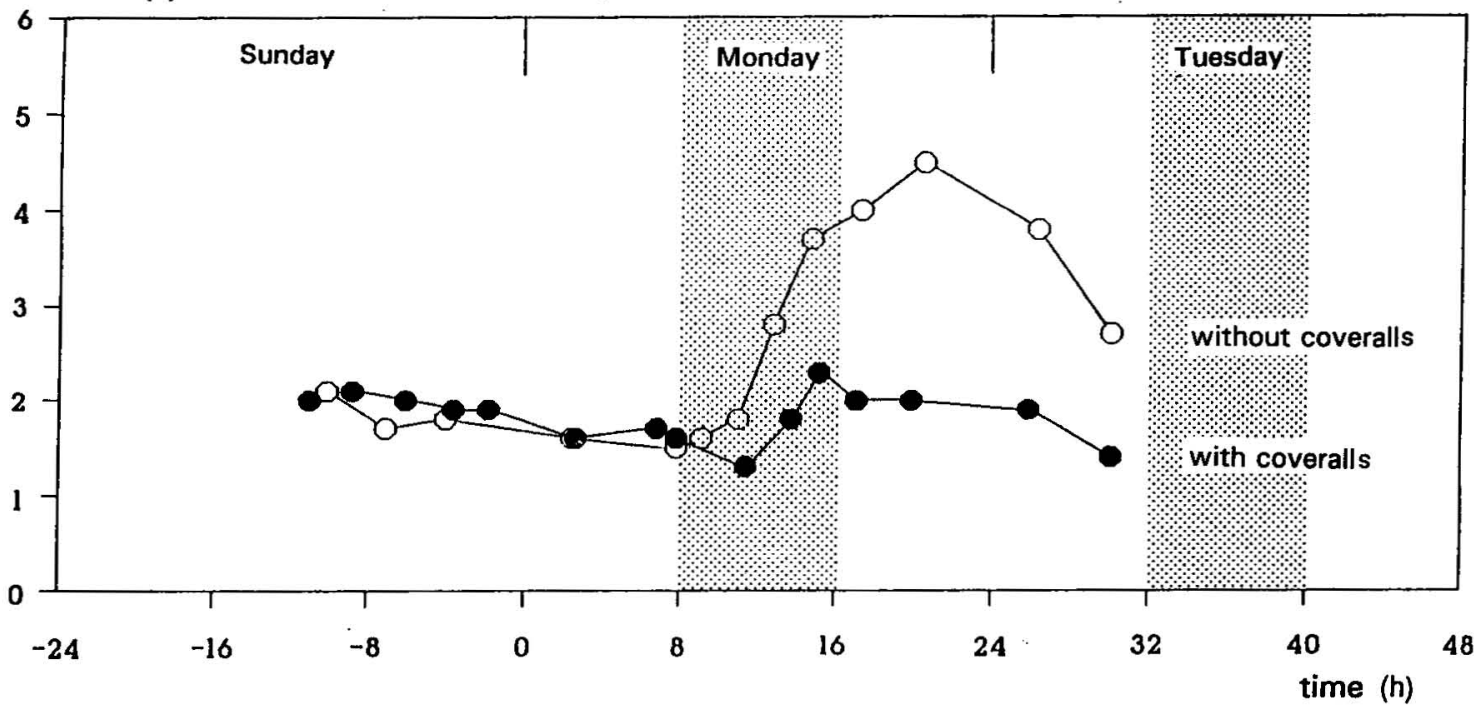

Figure 3. Effect of the coveralls on the urinary 1-OH-pyrene excretion of a creosote-exposed worker (worker 1). The shaded area indicates the hours of exposure (8-h workshift)

The rate of 1-OH-pyrene excretion was calculated as follows:

$$
\text { 1-OH-pyrene excretion rate }=C_{n} \cdot V_{n} /\left(t_{n}-t_{n-1}\right) \text {, }
$$

where, $C_{n}=$ the 1-OH-pyrene concentration in urine sample $n\left(\mathrm{nmol} \cdot \mathrm{l}^{-1}\right), V_{n}=$ volume of urine sample $n(1), t_{n}=$ time of voidance of urine sample $n(\mathrm{~h})$, $t_{n-1}=$ time of voidance of the urine sample before sample $n(\mathrm{~h})$.

The amount of 1-OH-pyrene excreted in the urine as a result of the 8 -h exposure period was calculated by determining the area under the curve (AUC) from $t=8 \mathrm{~h}$ until $\mathrm{t}=30 \mathrm{~h}$ of the "excretion rate versus time plots," corrected for the background ex- cretion in the same period. The individual background excretion in that period was calculated with the excretion rate before the exposure period. The urine on Monday morning may have contained a small amount of 1-OH-pyrene due to pyrene exposure on the previous Friday. For coke-oven workers Jongeneelen and his co-workers estimated that the half-time of 1-OH-pyrene varies between 6 and $35 \mathrm{~h}$ (22).

On the day the workers did not wear coveralls, the amount of urinary 1-OH-pyrene excreted as a result of an 8-h exposure was significantly higher $(6.6 \mu \mathrm{g}$ or $30.2 \mathrm{nmol}$ of $1-\mathrm{OH}$-pyrene) than on the day with the coveralls ( $3.2 \mu \mathrm{g}$ or $14.7 \mathrm{nmol}$ of $1-\mathrm{OH}$-pyrene) (table 2). 
Table 3. Results of the multiple regression analysis - the effect of differences in the pyrene skin contamination and breathing zone air concentration on the internal dose (urinary $1-\mathrm{OH}$-pyrene) of the creosote workers. Model: $\Delta$ urinary $1-\mathrm{OH}$-pyrene $=$ $\Delta$ pyrene skin contamination $+\Delta$ pyrene air concentration. ${ }^{a}$

\begin{tabular}{|c|c|c|c|c|}
\hline & $\begin{array}{l}\text { Parameter } \\
\text { estimate }\end{array}$ & SE & $\begin{array}{c}\text { Standardized } \\
\text { estimate }\end{array}$ & P-value \\
\hline $\begin{array}{l}\Delta \text { pyrene skín contamination }\left(\mu \mathrm{g} \cdot \mathrm{d}^{-1} \text { ) }\right. \\
\Delta \text { pyrene air concentration }\left(\mu \mathrm{g} \cdot \mathrm{m}^{-3}\right) \\
\text { Intercept }\end{array}$ & $\begin{array}{l}0.008 \\
1.5 \\
1.3\end{array}$ & $\begin{array}{l}0.002 \\
0.9 \\
1.0\end{array}$ & $\begin{array}{l}0.79 \\
0.29\end{array}$ & $\begin{array}{l}0.003 \\
0.14 \\
0.24\end{array}$ \\
\hline
\end{tabular}

a $\Delta=$ the difference between the two days of measurements (day without coveralls - day with coveralls) $N=10, R^{2}=0.79$.

\section{Relation between external exposure and internal dose}

The wearing of coveralls resulted in a significant reduction in both the pyrene skin contamination and the internal dose. The differences between the pyrene skin contamination correlated well with the differences in the urinary 1-OH-pyrene excretion $\left(\mathrm{r}_{\mathrm{S}}=\right.$ $0.93, \mathrm{P}=0.0001, \mathrm{~N}=10$ ). The differences in the concentrations in the breathing-zone air were not reflected in the differences in the urinary 1-OH-pyrene excretion $\left(r_{s}=0.39, P=0.26, N=10\right)$. Multiple regression analysis with the difference in urinary 1-OH-pyrene excretion as the dependent variable and the difference in pyrene skin contamination and the difference in the pyrene concentration in the breathing-zone air as the independent variables revealed a standardized parameter estimate of 0.79 for skin contamination and 0.29 for the concentration in breathing-zone air (table 3 ). This finding indicates that the internal dose was more determined by skin contamination than by the concentration in the breathingzone air.

\section{Discussion}

Data on the skin contamination of workers exposed to PAH are very limited. In previous studies dermal PAH contamination has been measured with exposure pads on road paving workers (17) and workers in the primary aluminum industry (7) and coke industry (8). The daily pyrene skin contamination of the creosote workers was relatively high (median $350 \mu \mathrm{g}$ or $1.7 \mu \mathrm{mol}$ of pyrene) in comparison with that of the coke-oven workers $(70 \mu \mathrm{g}$ or $0.3 \mu \mathrm{mol})$, primary aluminum workers $(395 \mu \mathrm{g}$ or $2.0 \mu \mathrm{mol})$, and road-paving workers $(117 \mu \mathrm{g}$ or $0.6 \mu \mathrm{mol})$. This difference does not necessarily mean that the total PAH contamination was also higher because the composition of the contaminant varied between the several work environments. The creosote oil used in the wood impregnation plant contained about $3.4 \%$ pyrene and less than $0.0004 \%$ benzo[a]pyrene. Coal tar, which is the main PAH contaminant in the coke industry, primary aluminum industry and tar road paving, contains about $2-10 \%$ pyrene and $0.4-$ $0.6 \%$ benzo[a]pyrene (5). The pyrene concentration in the breathing-zone air of the creosote workers ranged between 0.3 and $3.0 \mu \mathrm{g} \cdot \mathrm{m}^{-3}(1.5$ and 14.8 nmol $\cdot \mathrm{m}^{-3}$ ) (table 2). This range is comparable with concentrations in the breathing-zone air of workers in impregnation plants in Finland (23).

In a previous study among coke-oven workers about $20 \%$ of the daily pyrene skin contamination entered the body during an 8-h workshift, and the uptake of pyrene through inhalation was approximately $50 \%$ of the total amount of inhaled pyrene (8). Applying the results of these assessments in the present study revealed that 9.4 to 302 (median 69) $\mu \mathrm{g}$ [46 to 1490 (median 340) nmol] of pyrene entered the body through the skin during an 8-h workshift, and the estimated daily respiratory uptake of pyrene varied between 1.5 and 15 (median 4.5, assuming a respiration volume of $10 \mathrm{~m}^{3}$ in $8 \mathrm{~h}$ ) $\mu \mathrm{g}$ [7.4 and 74 (median 22) nmol] of pyrene. The results of these calculations show that the dermal pyrene uptake was on the average 15 -fold higher than the estimated respiratory uptake. The assumptions made in the calculations of pyrene uptake are open to discussion and modification. For example, the respiratory PAH uptake for creosote workers might have been underestimated because these workers inhale more pyrene in the gas form $( \pm 50 \%)$ than coke-oven workers do $( \pm 25 \%)(8)$. It is also unclear whether this relatively high concentration of gaseous pyrene in air affects the dermal pyrene uptake. However, it is not expected that the orders of magnitude of the calculated dermal and respiratory PAH uptake would be altered extremely.

The relevance of the skin as a route of PAH uptake was confirmed when both the dermal and the respiratory exposure was related to the internal dose. For the creosote workers who participated in this study it was shown that skin contamination was the main determinant of the internal dose and that a reduction of the concentration in breathing-zone air had a minor effect on the internal dose (table 3 ).

The present study shows that the extra protective clothing did not reduce the dermal PAH contamination very effectively (an average of about $35 \%$ ). Three out of ten workers showed a higher skin contamination despite the fact that they wore coveralls (table 2). This result might have been caused by either penetration of the contaminant through the Tyvek $^{\otimes}$ material, variation in exposure between the $2 \mathrm{~d}$ of measurement, or uncovered skin areas. Penetration of PAH through the material was not detected. 
That the variation in exposure might have affected the reduction of skin contamination is shown in table 2 . The breathing-zone air concentrations of the workers whose skin contamination was not reduced were indeed higher on the day they wore coveralls. In previous studies among other PAH-exposed workers it was also found that the interday variation of skin contamination is rather high (publication in preparation). However, the most important explanation for the low efficacy of the coveralls seems to be the uncovered skin areas, such as the face, wrists, and ankles (figure 1). The coveralls did not result in a significant reduction in contamination of the pads pasted on these skin areas (figure 2). In addition, low but measurable skin contamination was also found on pads pasted on skin regions which were definitely covered by the coveralls, such as the shoulder, upper arm, and groin. The contamination on these exposure pads showed a significant correlation with the pyrene concentration in the breathing-zone air of the workers $\left(r_{s}\right.$ was $0.58,0.85$ and 0.61 , respectively, $\mathrm{P} \leq 0.05)$. Apparently air is sucked between the skin and the coveralls, the result being deposition of PAH on skin. The contamination of the pads pasted under the normal workclothes showed no significant correlation with pyrene in the breathing zone of the workers. This finding indicates that contact with contaminated workclothes is the main source of contamination.

Wearing the Tyvek ${ }^{\oplus}$ coveralls underneath normal workclothes was not very comfortable for the workers, but necessary to avoid skin contamination from contaminated workclothes. Coveralls may reduce skin contamination, but they also may increase the dermal absorption rate of contaminants due to the elevated temperature of the skin, humidity, and physical stress.

The calculated dermal and respiratory uptake, the high correlation between dermal exposure and urinary 1-OH-pyrene excretion, and the low correlation between the air concentration and urinary $1-\mathrm{OH}-$ pyrene excretion lead us to conclude that, for the group of wood-preserving workers who participated in this study, the skin is the main route of PAH uptake. Measures to reduce the internal dose of PAHexposed workers should primarily be focused on reducing dermal PAH contamination. The coveralls, as applied in this study, were not very effective in reducing dermal PAH contamination, probably due to uncovered skin areas such as the face, wrists, and ankles. Further research should clarify whether frequent cleaning of workclothes, combined with improved personal hygiene, leads to a satisfactory reduction in the internal dose of PAH-exposed workers.

\section{Acknowledgments}

The authors thank the creosote workers and the medical officer of the wood-impregnating plant, A Lub- bers, MD, Occupational Health Service, Nederlandse Spoorwegen NV, Roosendaal, The Netherlands, for their support and contribution.

This study was financially supported by the European Community on Coal and Steel (ECCS), contract $7280 / 01 / 002$.

\section{References}

1. Wright $\mathrm{CW}$, Later DW, Wilson BW. Comparative chemical analysis of commercial creosotes and solvent refined coal - II. materials by high resolution gas chromatography. J High Res Chrom Chrom Commun 1985;8:283-89.

2. Lorenz LF, Gjovik LR. Analyzing creosote by gas chromatography: relationship to creosote specifications. In: American Wood-Preservers' Association. Proceedings of the annual meeting of the American Wood-Preservers' Association; 1972. Stevensville, MD: American Wood-Preservers' Association, 1972: $32-42$.

3. Nylund L, Heikkilä P, Hämeilä M, Pyy L, Linnainmaa $\mathrm{K}$, Sorsa M. Genotoxic effects and chemical compositions of four creosotes. Mutation Res 1992;265: $223-36$

4. Schoket B, Hewer A, Grover PL, Phillips DH. Covalent binding of components of coal-tar, creosote and bitumen to the DNA of the skin and lungs of mice following topical application. Carcinogenesis 1988;9: $1253-8$.

5. International Agency for Research on Cancer (IARC). Polynuclear aromatic compounds: Part 4 . bitumens, coal-tars and derived products, shale-oils and soots. Lyon: IARC, 1985. (IARC monographs on the evaluation of the carcinogenic risk of chemicals to humans; vol 35.)

6. Karlehagen S, Andersen A, Ohlson C-G. Cancer incidence among creosote-exposed workers. Scand J Work Environ Health 1992;18:26-9.

7. Van Rooij JGM, Bodelier-Bade MM, De Looff AJA, Dijkmans APG, Jongeneelen FJ. Dermal exposure to polycyclic aromatic hydrocarbons among primary aluminum workers. Med Lav 1992;83(5):519-29.

8. Van Rooij JGM, Bodelier-Bade MM, Jongeneelen FJ. Estimation of the individual dermal and respiratory uptake of polycyclic aromatic hydrocarbons of 12 coke-oven workers. Br J Ind Med. In press.

9. Laidlaw JL, Connor TH, Theiss JC, Anderson RW, Matney TS. Permeability of four disposable protectiveclothing materials to seven antineoplastic drugs. Am J Hosp Pharm 1985;42:2449-54.

10. Stampfer JF, McLeod MJ, Betts MR, Martinez AM, Berardinelli SP. Permeation of polychlorinated biphenyls and solutions of these substances through selected protective clothing materials. Am Ind Hyg Assoc J 1984;45:634-41.

11. Stampfer JF, McLeod MJ, Betts MR, Martinez AM, Berardinelli SP. Permeation of eleven protective garment materials by four organic solvents. Am Ind Hyg Assoc J 1984;45:642-54.

12. Buckley TJ, Lioy PJ. An examination of the time course from human dietary exposure to polycyclic aromatic hydrocarbons to urinary elimination of 1-hydroxypyrene. Br J Ind Med 1992;49:113-24.

13. Clonfero $E$, Zordan $M$, Venier $P$, Paleologo $M$, Levis AG, Cottica D, et al. Biological monitoring of human exposure to coal tar: urinary excretion of total poly cyclic aromatic hydrocarbons, 1-hydroxypyrene and mutagens in psoriatric patients. Int Arch Occup Environ Health 1989;61:363-8.

14. Jongeneelen FJ, Anzion RBM, Scheepers PTJ, Bos, 
RP, Henderson PT, Nijenhuis EH, et al. 1-Hydroxypyrene in urine as a biological indicator of exposure to polycylic aromatic hydrocarbons in several work environments. Ann Occup Hyg 1988;32:35-43.

15. Tolos WP, Shaw PB, Lowry LK, MacKenzie BA, Deng JF, Markel HL. 1-Pyrenol: a biomarker for occupational exposure to polycyclic aromatic hydrocarbons. Appl Occup Environ Hyg 1990;5:303-9.

16. Zhao ZH, Quan WY, Tian DH. Urinary 1-hydroxypyrene as an indicator of human exposure to ambient polycyclic aromatic hydrocarbons in a coal-burning environment. Sci Total Environ 1990;92:145-54.

17. Jongeneelen FJ, Scheepers PTJ, Groenendijk A, Von Aerts LA, Anzion RB, Bos RP, et al. Airborne concentrations, skin contamination, urinary metabolite excretion of polycyclic aromatic hydrocarbons among paving workers exposed to coal tar derived road tars. Am Ind Hyg Assoc J 1988;49:600-7.

18. Popendorf WJ, Leffingwell JT. Regulating OP pesticide residues for farmworker protection. In: Residues of pesticides and other contaminants in the total environment. New York, NY: Springer-Verlag, 1982: 125-201. (Residue reviews; vol 82.)

19. Du Bois D, Du Bois E. A formula to estimate the ap- proximate surface if height and weight be known. Arch Intern Med 1916;863-71.

20. Staubforschungs Institut. Empfelungen zur messung und beurteilung von gesundheitsgefährlichen stauben [Recommendations for the determination of healthdamaging particulate matter]. Staub Reinhalt Luft 1973;3:1-3.

21. Jongeneelen FJ, Anzion RBM, Henderson PT. Determination of hydroxylated metabolites of polycyclic aromatic hydrocarbons in urine. J Chromatogr 1987; 413:227-32.

22. Jongeneelen FJ, van Leeuwen FE, Oosterink S, Anzion RBM, van der Loop F, Bos RP, et al. Ambient and biological monitoring of cokeoven workers: determinants of the internal dose of polycyclic aromatic hydrocarbons. Br J Ind Med 1990;47:454-61.

23. Heikkilä PR, Hämeilä M, Pyy L, Raunu P. Exposure to creosote in the impregnation and handling of impregnated wood. Scand J Work Environ Health 1987;13:431-7.

Received for publication: 27 October 1992 